\title{
THE EFFECT OF TOTAL SYMPATHECTOMY ON THE OCCURRENCE OF SHOCK FROM HEMORRHAGE
}

\author{
By N. E. FREEMAN, S. A. SHAFFER, A. E. SCHECTER ANd H. E. HOLLING ${ }^{1}$ \\ WITH THE TECHNICAL ASSISTANCE OF N. E. MAREAN \\ (From the Harrison Department of Surgical Reseurch, School of Medicine, University of \\ Pennsylvania, Philadelphia)
}

(Received for publication January 20, 1938)

Shock has been differentiated from hemorrhage on the basis of hemoconcentration, negative reaction to blood transfusions, and pathological changes in the tissues (1). In hemorrhage, dilution of the blood occurs while concentration takes place in shock. After simple loss of blood, prompt recovery follows transfusion, whereas in severe shock, the administration of blood is frequently unavailing. It has been held that the tissues are anemic after hemorrhage while the pathological picture of shock is that of " dilatation and engorgement of capillaries and vessels" (2). Blalock, however, in a convincing series of experiments (3), showed that the classical picture of shock with hemoconcentration, negative reaction to transfusion, and pathological changes in the tissues, could be produced by hemorrhage alone. In his experiments on dogs under local anesthesia, the blood pressure was maintained at a low level for several hours by means of hemorrhage. At the end of this time, in spite of the fact that all the blood which had been removed was reinjected, the blood pressure continued to fall and the animal died. The present experiments were performed to investigate further the mechanism through which shock was produced by hemorrhage.

It is recognized that vasoconstriction takes place after hemorrhage and this reaction has been described as protective (4). By means of contraction of the vessels in the presence of hemorrhage, the blood pressure is maintained at a level compatible with life. After removal of the vasoconstrictors by complete sympathectomy, cats under anesthesia are unable to tolerate as great a loss of blood as normal animals (5). In a former communication (6), it was shown, on the other hand, that intense and prolonged vasoconstriction caused a reduction in blood volume and

\footnotetext{
1 Travelling Fellow of the British Medical Research Council.
}

shock in the experimental animal. This apparent paradox was attributed to a reduction in the volume flow of blood to the peripheral tissues produced by constriction of the arterioles. The hypothesis was advanced that vasoconstriction enabled the organism to adjust to the immediate crisis. If this reaction were so intense and protracted, however, as to reduce the nutrient flow to the tissues, shock would be produced.

The reaction of normal dogs to hemorrhage was, therefore, compared with that of completely sympathectomized dogs. Particular attention was paid to the function of vasoconstriction in maintaining blood pressure, and at the same time in restricting the flow of blood to the peripheral tissues. Arterial blood pressure was correlated with the volume flow of blood through the paw.

Death or recovery of the dog was used as the ultimate criterion of shock. Concentration of the peripheral blood, alterations in the oxygen and carbon dioxide contents of the arterial and venous blood, and the reactions of the dogs to transfusions were noted. At the end of the experiments various tissues were examined histologically.

\section{METHODS}

Dogs were used which weighed between 11 and 22 kilograms. Under aseptic precautions, cannulae were inserted into the carotid artery and the jugular vein, or the femoral artery and vein. Pain was prevented by the use of novocain in the operative wounds. The blood pressure was determined by means of a Hürtle manometer, calibrated with a mercury manometer. Blood was obtained for analysis of the oxygen content and capacity and carbon dioxide content from the carotid artery and from the right heart. The blood was taken under oil, chilled, and analyzed at the conclusion of the experiment. The oxygen content and capacity, and the carbon dioxide content were determined by the method of Van Slyke and Neill (7). In certain of the experiments the plasma volume was determined by the method of Greger- 
TABLE I

Data compiled from all the experiments on hemorrhage in the normal and sympathectomized dogs

\begin{tabular}{|c|c|c|c|c|c|c|c|c|c|c|c|c|c|c|c|c|}
\hline \multirow{2}{*}{$\underset{\text { ber }}{\text { Dog }}$} & \multirow{2}{*}{ Weight } & \multirow{2}{*}{$\begin{array}{c}\text { Plasma } \\
\text { vol- } \\
\text { ume }\end{array}$} & \multirow{2}{*}{$\begin{array}{l}\text { Initial } \\
\text { bleed- } \\
\text { Ing }\end{array}$} & \multirow{2}{*}{$\begin{array}{l}\text { Per } \\
\text { cent } \\
\text { of } \\
\text { body } \\
\text { weight }\end{array}$} & \multirow{2}{*}{$\begin{array}{c}\text { Time } \\
\text { of } \\
\text { initial } \\
\text { bleed- } \\
\text { ing }\end{array}$} & \multirow{2}{*}{$\begin{array}{c}\text { Total } \\
\text { hemor- } \\
\text { rhage }\end{array}$} & \multirow{2}{*}{$\begin{array}{c}\text { Amount } \\
\text { trans } \\
\text { fused }\end{array}$} & \multicolumn{3}{|c|}{ Hemoglobin } & \multicolumn{3}{|c|}{ Average after hemorrhage* } & \multicolumn{2}{|c|}{ After transfusion } & \multirow{2}{*}{ Result } \\
\hline & & & & & & & & Start & $\begin{array}{l}\text { mum } \\
\text { dilu- } \\
\text { tion }\end{array}$ & $\begin{array}{c}\text { tration } \\
\text { after } \\
\text { dilution }\end{array}$ & $\underset{\text { pressure }}{\text { Blood }}$ & $\begin{array}{c}\text { Blood } \\
\text { flow }\end{array}$ & $\begin{array}{c}\text { Dura- } \\
\text { tion }\end{array}$ & $\underset{\text { pressure }}{\text { Blood }}$ & $\begin{array}{l}\text { Blood } \\
\text { flow }\end{array}$ & \\
\hline & kilos & cc. & $c$. & & hours & cc. & c. & per cent & per cent & per cenl & mm. $\mathrm{Hg}$ & $\begin{array}{l}\text { ce. per } \\
100 \text { cc. } \\
\text { paw noi- } \\
\text { ume per } \\
\text { minute }\end{array}$ & hours & $m m . H g$ & $\begin{array}{l}\text { ce. per } \\
100 \text { cc. } \\
\text { pawo sol- } \\
\text { ume per } \\
\text { minute }\end{array}$ & \\
\hline
\end{tabular}

NORMAL DOGS-DIED

\begin{tabular}{|c|c|c|c|c|c|c|c|c|c|c|c|c|c|c|c|c|}
\hline $\begin{array}{r}25 \\
16 \\
751\end{array}$ & $\begin{array}{l}14.2 \\
18.8 \\
13.6\end{array}$ & $\begin{array}{r}1010 \\
742\end{array}$ & $\begin{array}{r}766 \\
814 \\
1000\end{array}$ & $\begin{array}{l}5.4 \\
4.3 \\
7.3\end{array}$ & $\begin{array}{l}3.6 \\
1.4 \\
1.9\end{array}$ & $\begin{array}{r}766 \\
889 \\
1153\end{array}$ & $\begin{array}{l}830 \\
845 \\
820\end{array}$ & $\begin{array}{r}106 \\
78 \\
115\end{array}$ & $\begin{array}{l}94 \\
64 \\
68\end{array}$ & $\begin{array}{r}117 \\
83 \\
95\end{array}$ & $\begin{array}{l}67 \\
70 \\
60\end{array}$ & $\begin{array}{l}0.9 \\
1.5 \\
0.4\end{array}$ & $\begin{array}{l}6.6 \\
2.1 \\
4.6\end{array}$ & $\begin{array}{l}60 \\
50 \\
85\end{array}$ & $\begin{array}{l}0 \\
1.0 \\
0.8\end{array}$ & $\begin{array}{l}\text { Died } \\
\text { Died } \\
\text { Died during rein- }\end{array}$ \\
\hline $\begin{array}{r}767 \\
570 \\
2\end{array}$ & $\begin{array}{l}17.4 \\
14.7 \\
14.7\end{array}$ & $\begin{array}{l}800 \\
718\end{array}$ & $\begin{array}{r}907 \\
553 \\
1098\end{array}$ & $\begin{array}{l}5.2 \\
3.8 \\
7.5\end{array}$ & $\begin{array}{l}1.9 \\
2.8 \\
1.4\end{array}$ & $\begin{array}{r}1032 \\
708 \\
1055\end{array}$ & $\begin{array}{l}173 \\
680 \\
465\end{array}$ & $\begin{array}{l}110 \\
100\end{array}$ & $\begin{array}{l}80 \\
88\end{array}$ & 92 & $\begin{array}{l}62 \\
49 \\
42\end{array}$ & $\begin{array}{l}0.9 \\
0.1 \\
0.1\end{array}$ & $\begin{array}{l}2.4 \\
3.6 \\
2.0\end{array}$ & $\begin{array}{l}50 \\
40 \\
30\end{array}$ & 0 & $\begin{array}{l}\text { Acute cardiac failure } \\
\text { Died } \\
\text { Died during rein- }\end{array}$ \\
\hline 546 & 22.0 & & 1000 & 4.5 & 1.4 & 1000 & 1030 & & & & 38 & 1.6 & 3.5 & 42 & 2.5 & Died \\
\hline
\end{tabular}

NORMLL DOGS-RACOVERED

\begin{tabular}{|c|c|c|c|c|c|c|c|c|c|c|c|c|c|c|c|}
\hline $\begin{array}{l}546 \\
641\end{array}$ & $\begin{array}{l}22.0 \\
11.6\end{array}$ & 800 & $\begin{array}{l}980 \\
686\end{array}$ & $\begin{array}{l}4.5 \\
5.9\end{array}$ & $\begin{array}{l}1.8 \\
1.5\end{array}$ & $\begin{array}{r}1217 \\
860\end{array}$ & $\begin{array}{l}900 \\
845\end{array}$ & $\begin{array}{r}86 \\
103\end{array}$ & $\begin{array}{l}62 \\
61\end{array}$ & $\begin{array}{l}69 \\
63\end{array}$ & $\begin{array}{l}2.9 \\
2.1\end{array}$ & $\begin{array}{l}2.2 \\
6.0\end{array}$ & $\begin{array}{r}130 \\
96\end{array}$ & $\begin{array}{l}20.4 \\
12.2\end{array}$ & $\begin{array}{l}\text { Recovered } \\
\text { Recovered-sacrificed }\end{array}$ \\
\hline
\end{tabular}

BYMPATHECTOMTAD DOGS

\begin{tabular}{|c|c|c|c|c|c|c|c|c|c|c|c|c|c|c|c|c|}
\hline $\begin{array}{r}385 \\
418 \\
14\end{array}$ & $\begin{array}{l}14.7 \\
14.0 \\
14.0\end{array}$ & $\begin{array}{l}870 \\
950\end{array}$ & $\begin{array}{l}512 \\
488 \\
504\end{array}$ & $\begin{array}{l}3.5 \\
3.5 \\
\mathbf{3 . 6}\end{array}$ & $\begin{array}{l}1.5 \\
1.0 \\
1.0\end{array}$ & $\begin{array}{l}644 \\
684 \\
581\end{array}$ & $\begin{array}{l}436 \\
560 \\
513\end{array}$ & $\begin{array}{l}75 \\
82\end{array}$ & $\begin{array}{l}56 \\
65\end{array}$ & 65 & $\begin{array}{l}\mathbf{5 2} \\
\mathbf{5 5} \\
\mathbf{5 0}\end{array}$ & $\begin{array}{l}1.2 \\
1.9 \\
0.8\end{array}$ & $\begin{array}{l}3.9 \\
5.6 \\
4.7\end{array}$ & $\begin{array}{l}120 \\
120 \\
168\end{array}$ & $\begin{array}{r}9.6 \\
16.2 \\
38.0\end{array}$ & $\begin{array}{l}\text { Recovered-sacrificed } \\
\text { Rocovered_living } \\
\text { Recovered-living }\end{array}$ \\
\hline
\end{tabular}

* The average blood pressure and blood flow, after hemorrhage was calculated with a planimeter.

sen (8). ${ }^{2}$ Hemoglobin estimations were made by the Sahli method on blood taken from the ear. The volume flow of blood through the hind paw was determined by the plethysmographic method previously described (9). The temperature of the water bath in which the paw was immersed was kept between $36^{\circ}$ and $39^{\circ} \mathrm{C}$.

The dogs were bled from the carotid or femoral arteries into a sterile container which contained 2.5 per cent sodium citrate solution. The final dilution of citrate in blood was 0.25 per cent.

After control observations on blood pressure and blood flow were made, the dogs were bled at frequent intervals until the blood pressure and blood flow were reduced to low levels from which rapid recovery did not occur. This period of hemorrhage is considered in Table $I$ to be the time of initial bleeding. It varied from 1.4 to 3.6 hours in the normal dogs and 1.0 to 1.5 hours in the sympathectomized dogs. After this period of initial bleeding, the dogs were allowed to continue with a low blood pressure and diminished blood flow as long as possible. If the blood pressure or blood flow started to rise, blood was again withdrawn. When the blood pressure started to decline spontaneously or if the dog showed signs of loss of consciousness, small amounts of blood were reinjected.

2 The blue dye T-1824 was obtained through the kindness of Doctor Gregersen.
Blood, which had been removed under aseptic precautions from donor dogs, was also injected in two of the experiments so that the total amount of blood which these animals received after hemorrhage was larger than the amount which was removed during the experiment.

Complete sympathectomy was performed by removal of the paravertebral sympathetic ganglia in three stages as described by Cannon (10). The sympathectomized dogs had fully recovered from the effects of the operative procedures at the time they were used in the experiments.

\section{RESULTS}

In the normal dog, after the blood pressure and blood flow had been reduced for a period of hours by hemorrhage, shock was produced. This condition was characterized by concentration of the peripheral blood, negative reaction to blood transfusion, and failure to recover. Figure 1 illustrates this reaction. In spite of the fact that the blood pressure at no time fell below 60 $\mathrm{mm}$. $\mathrm{Hg}$ the blood flow was reduced to a low level. At the end of three and one-half hours, the blood pressure failed to rise and the blood flow started to fall spontaneously. Blood was then 
Blood flow

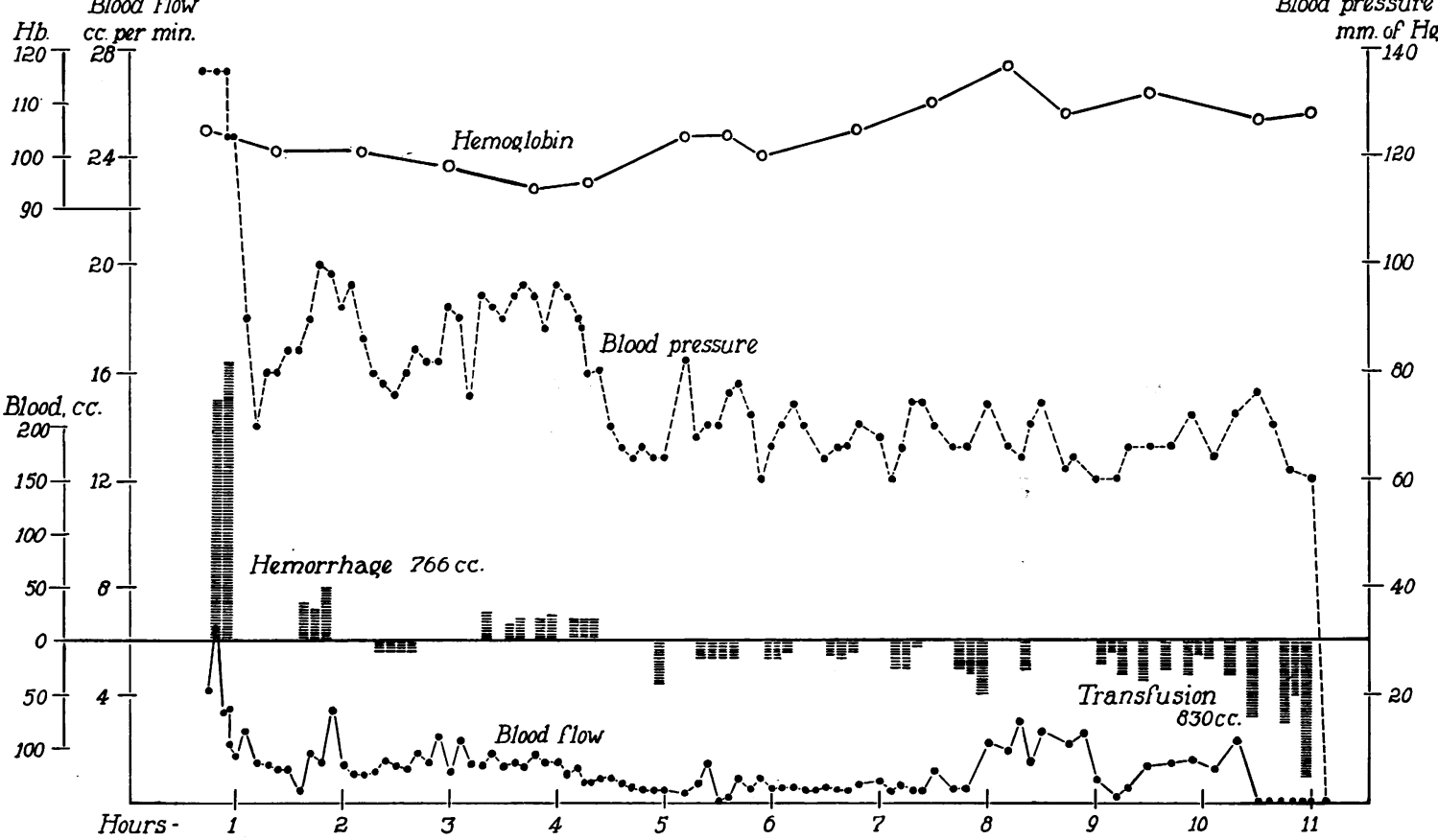

Fig. 1. Effect of Hemorrhage, Followed by Transfusion, on the Volume flow of Blood through the Hind Paw, the Blood Pressure, and the Hemoglobin Content of the Venous Blood in a Normal Dog. Dog 25, 14.2 Kilograms.

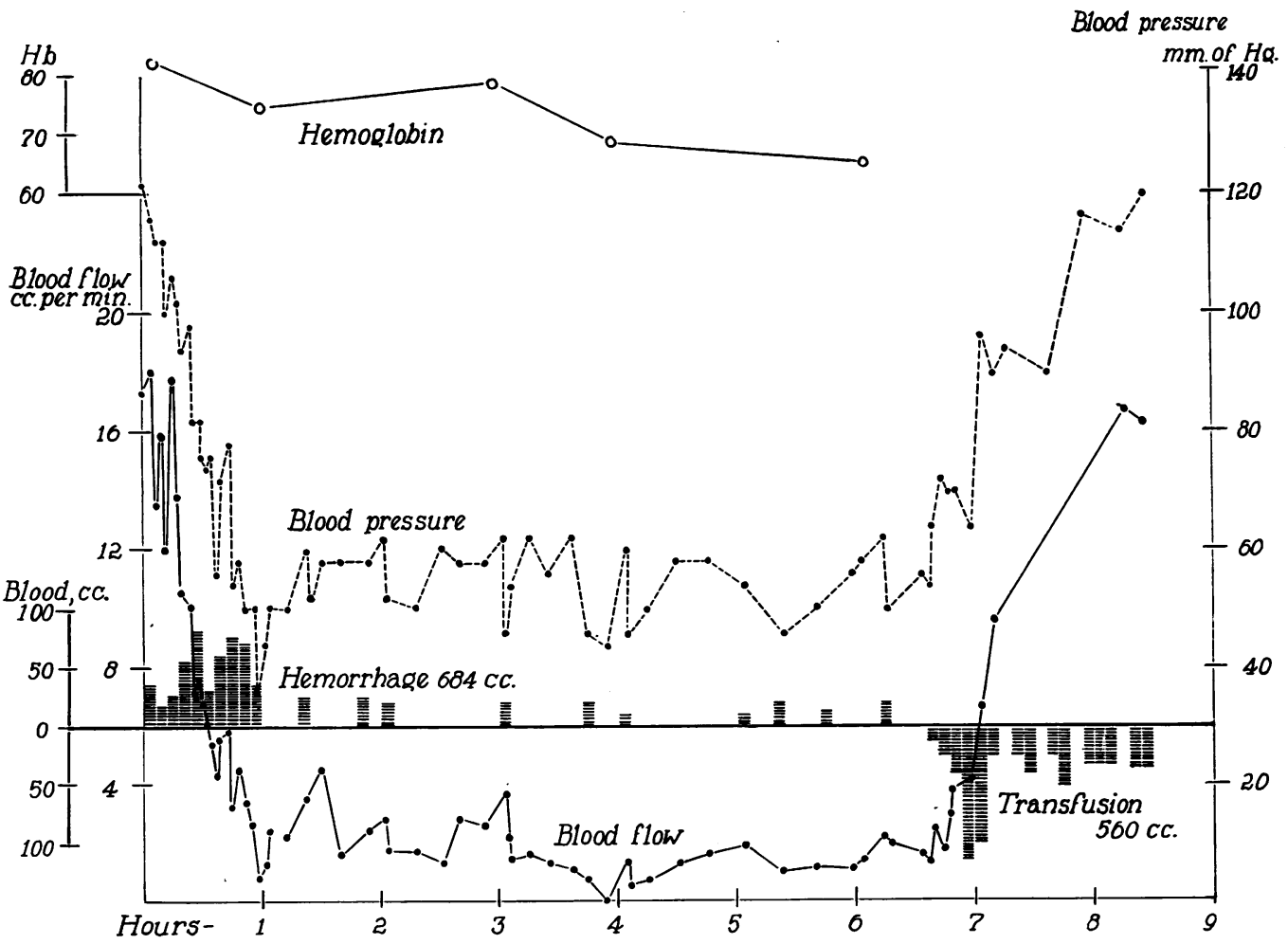

Fig. 2. Effect of Hemorrhage, Followed by Transfusion, on Volume Flow of Blood through the Hind Paw, the Blood Pressure, and the Hemoglobin Content of the Venous Blood in a Sympathectomized Dog. Dog 418, 14.0 Kilograms. 


\section{Liver}

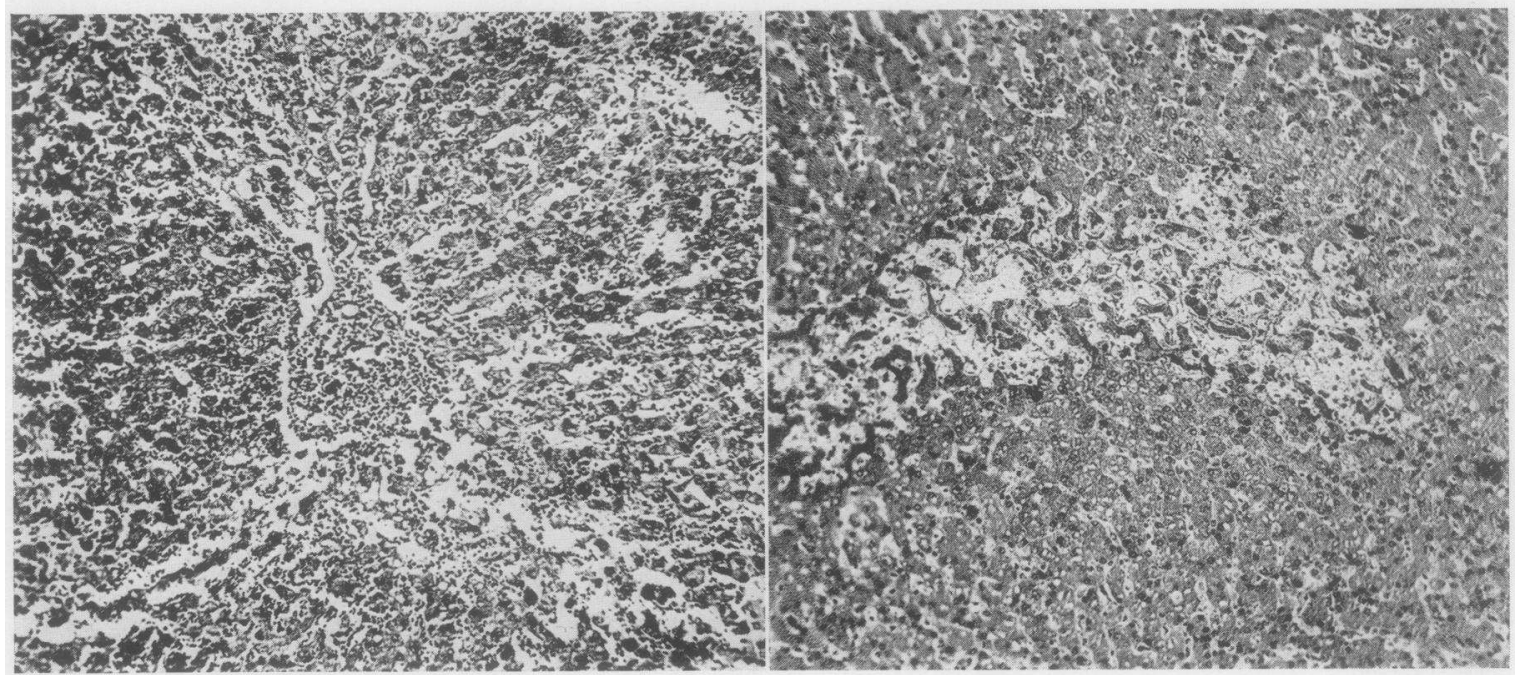

A

$B$

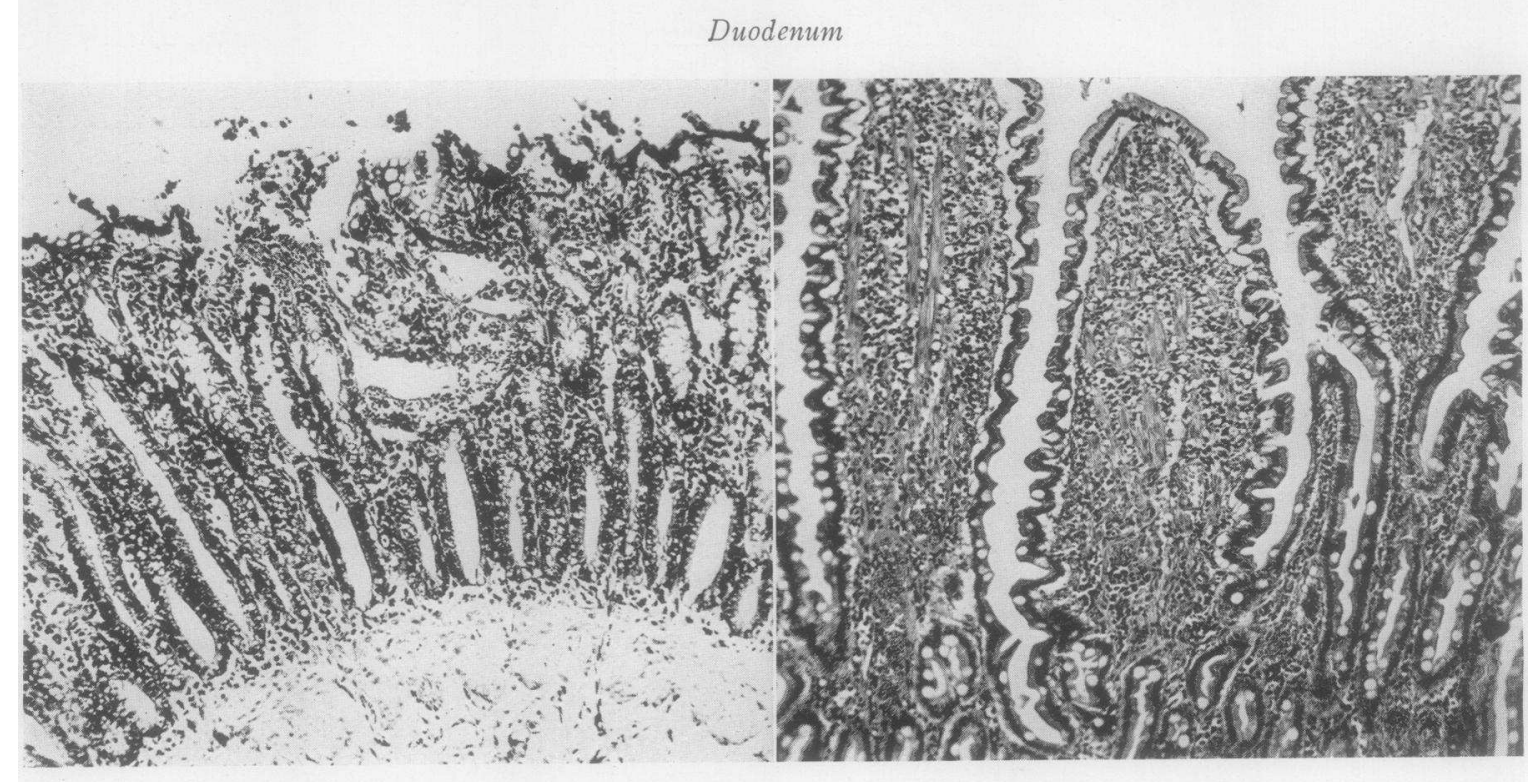

C

D

Fig. 3. Histological findings in the Liver $(A)$ and Duodenum $(C)$ of One of the Normal Dogs Which Died in Shock in Contrast to the Liver $(B)$ and Duodenum $(D)$ of one of the Sympathectomized Dogs Which Was Sacrificed after Recovery.

slowly reinjected. Over a period of six hours, although $64 \mathrm{cc}$. more blood were injected than had been removed, the blood pressure and blood flow failed to return to the original level. At the conclusion of the injection the dog died.

In the sympathectomized dog, as shown in Figure 2, although the blood pressure was reduced to below $60 \mathrm{~mm}$. Hg and maintained at this level for six hours before the reinjection of blood, the blood flow was not reduced to as great an extent, and recovery took place. Instead of hemoconcentration, dilution of the blood took place, even though the blood pressure was at a lower level than in the normal dog. The prompt response 
of blood pressure and blood flow to the reinjection of blood stands in contrast to the absence of response in the normal dog. At the conclusion of the experiment, the sympathectomized dog recovered completely and ran back to its cage.

The results obtained in nine experiments on normal dogs and three experiments on sympathectomized dogs are summarized in Table $I$. The amount of blood loss in proportion to the blood was minor but there were extensive patches of necrosis of the liver cells. In the duodenum of the shocked $\operatorname{dog}(C)$ the superficial portion of the mucous membrane had disappeared. This observation accorded with the fact that during the periods of low blood pressure, the shocked dogs always had profuse bloody diarrhea in which sloughs of the mucous membrane could be made out. The mucous membrane of the duodenum in

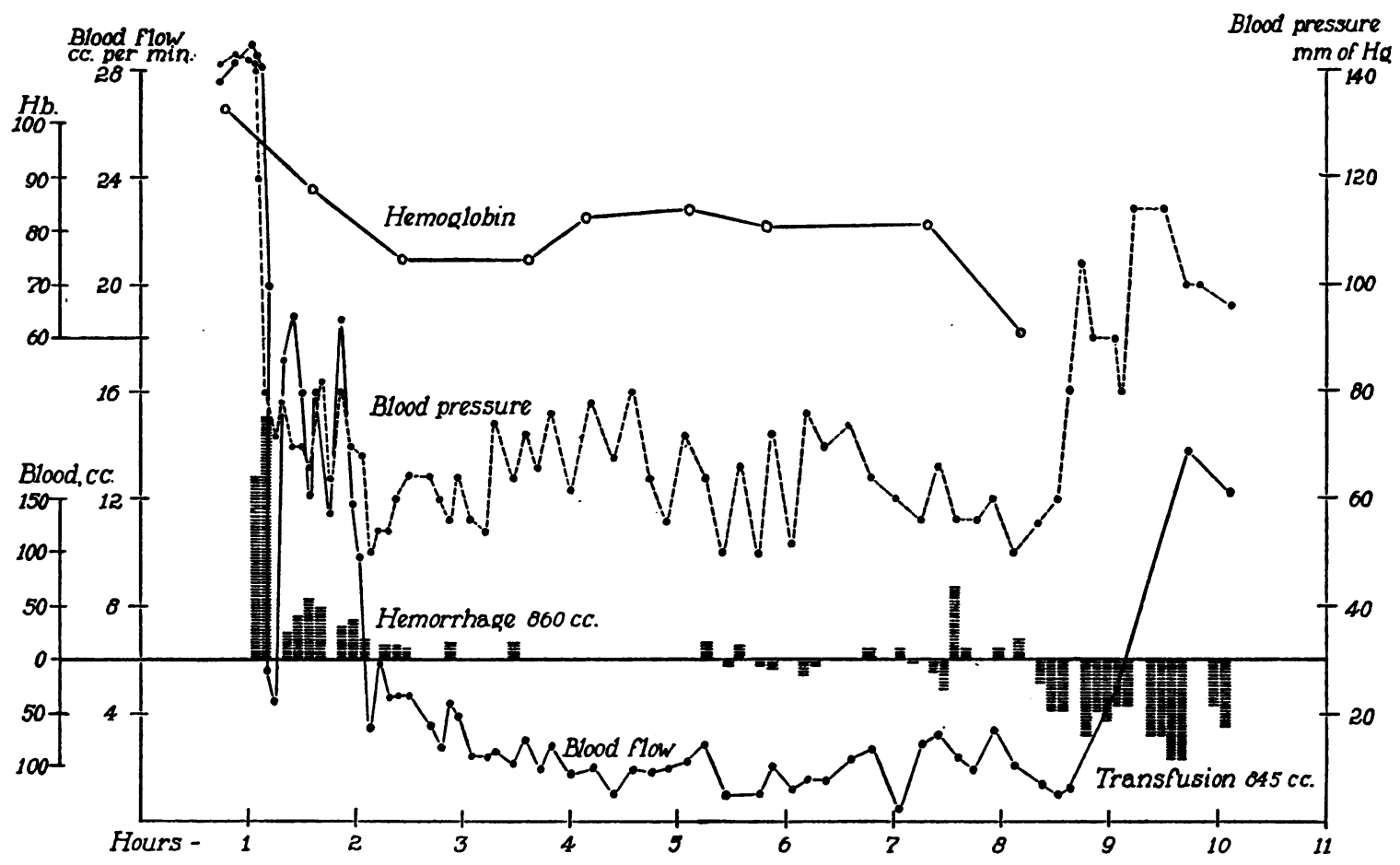

Fig. 4. Effect of Hemorrhage, Followed by Transfusion, on the Volume flow of Blood through the Hind Paw, the Blood Pressure, and the Hemoglobin Content of the Venous Blood in a Normal Dog Which Recovered. Dog 641, 11.6 KiLograms.

body weight was greater in the normal dogs ( 5.4 per cent) than in the sympathectomized dogs ( 3.6 per cent). The time necessary to reduce the blood pressure to a low level in the normal dogs (2.1 hours) was also greater than that required in the sympathectomized dogs (1.2 hours).

In Figure 3 are shown the contrasting histological pictures of one of the normal dogs which died in shock and one of the sympathectomized dogs which was sacrificed after recovery. The liver of the dog which died in shock $(A)$ showed tremendous engorgement with blood and some evidence of degeneration of the liver cells. In the sympathectomized $\operatorname{dog}(B)$ engorgement with the sympathectomized dog $(D)$ was preserved intact although there was tremendous engorgement of blood in the vessels.

In two of the normal dogs, recovery took place, even though the blood pressure had been reduced to a low level for six hours. The amount of hemorrhage was equivalent to that in the dogs which went into shock. Figure 4 illustrates the reaction in one of the dogs. It can be seen that the blood flow through the paw was not reduced to as great an extent as in the shocked dogs. Although concentration of the blood took place at one time in the experiment, considerable dilution occurred later. 


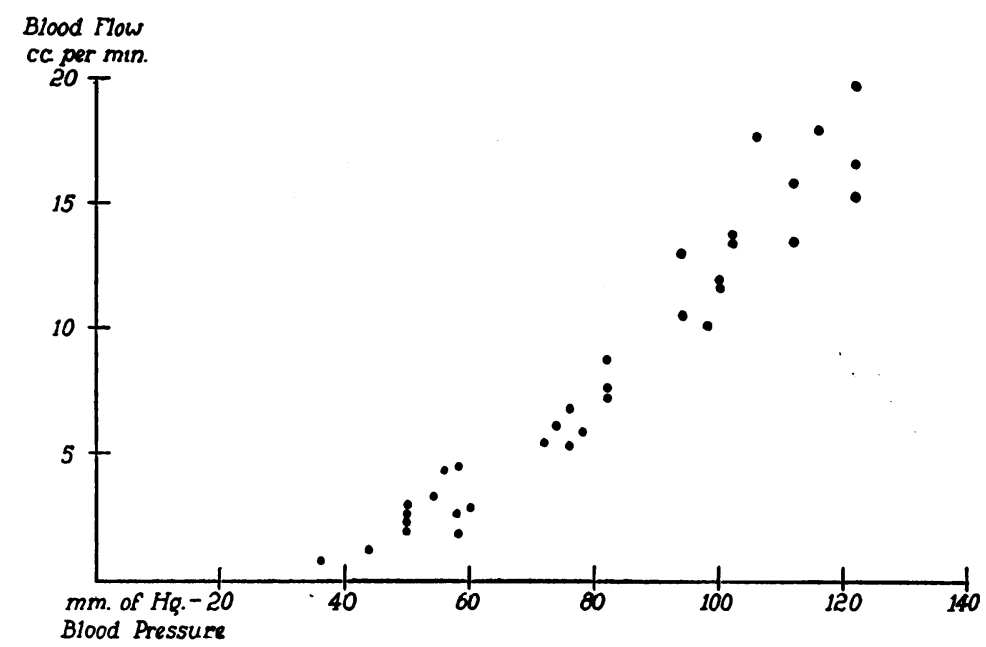

Fig. 5. Effect of Reducing Blood Pressure by means of Hemorrhage on Volume flow of Blood through the Hind Paw of a SympaTHECTOMIZED DoG.

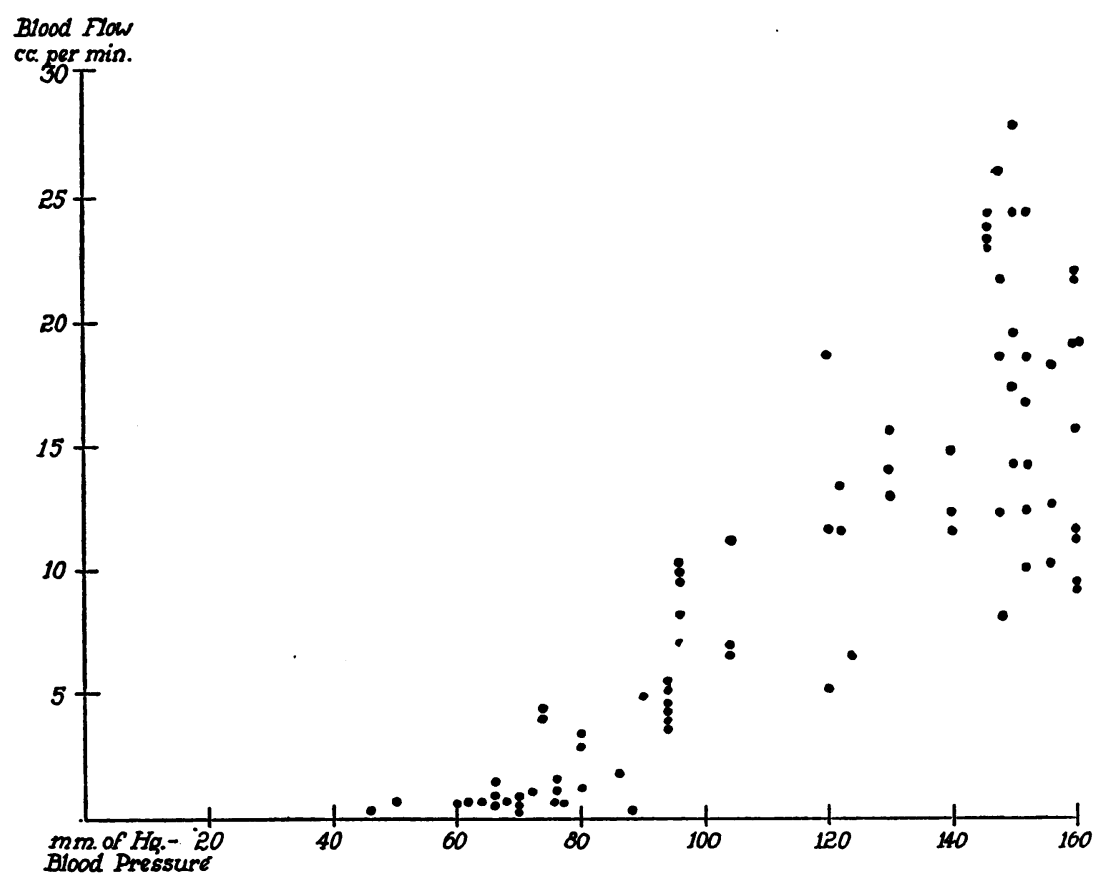

Fig. 6. Effect of Reducing Blood Pressure by Means of Hemorrhage on Volume flow of Blood through the Hind Paw of a Normal Dog

The influence of the vasomotor system on the relationship between blood pressure and blood flow is illustrated in Figures 5 and 6 . In the sympathectomized dog, the flow varied directly with the pressure. In the normal dog with intact vasomotor system wide variations in flow were encountered as the blood pressure was being reduced by hemorrhage. After the blood pressure dropped below $70 \mathrm{~mm}$. $\mathrm{Hg}$, the volume flow of blood remained constantly at a low level. Although the flow in the sympathectomized dog was considerably reduced, it was still above that of the normal dog at this level of blood pressure.

Analyses were made of the oxygen content and capacity and carbon dioxide content on the arterial and venous blood in one normal and one 
TABLE' II

Analyses of blood gases before and after hemorrhage in the normal dog in contrast to the sympathectomized dog

\begin{tabular}{|c|c|c|c|c|c|c|}
\hline \multirow[b]{2}{*}{ Dog number } & \multirow[b]{2}{*}{ Time } & \multicolumn{3}{|c|}{ Arterial blood } & \multicolumn{2}{|c|}{ Venous blood } \\
\hline & & $\begin{array}{l}\text { Oxy- } \\
\text { gen } \\
\text { con- } \\
\text { tent }\end{array}$ & $\begin{array}{l}\mathrm{CO}_{2} \\
\text { con- } \\
\text { tent }\end{array}$ & $\begin{array}{c}\text { Oxy- } \\
\text { gen } \\
\text { capac- } \\
\text { ity }\end{array}$ & $\begin{array}{l}\text { Oxy- } \\
\text { gen } \\
\text { con- } \\
\text { tent }\end{array}$ & $\begin{array}{l}\mathrm{CO}_{2} \\
\text { con- } \\
\text { tent }\end{array}$ \\
\hline \multirow{2}{*}{$\begin{array}{c}546 \\
\text { Normal } \\
\text { control }\end{array}$} & $\begin{array}{c}\text { Before } \\
\text { hemorrhage }\end{array}$ & $\begin{array}{c}\text { vol } \\
\text { umes } \\
\text { per } \\
\text { cent } \\
13.9\end{array}$ & $\begin{array}{c}\text { vol } \\
\text { umes } \\
\text { per } \\
\text { cent } \\
45.2\end{array}$ & $\begin{array}{c}\text { volumes } \\
\text { per cent } \\
14.6\end{array}$ & $\begin{array}{c}\begin{array}{c}\text { volumes } \\
\text { per cent } \\
11.0\end{array} \\
11.0\end{array}$ & $\begin{array}{l}\text { rol- } \\
\text { umes } \\
\text { per } \\
\text { cent } \\
\mathbf{4 8 . 2}\end{array}$ \\
\hline & Shock & 14.5 & 15.1 & 15.3 & 4.6 & 23.9 \\
\hline \multirow{2}{*}{$\begin{array}{c}14 \\
\text { Sympathec- } \\
\text { tomized }\end{array}$} & $\begin{array}{c}\text { Before } \\
\text { hemorrhage }\end{array}$ & 16.0 & 45.3 & 17.6 & 11.0 & 49.3 \\
\hline & $\begin{array}{c}\text { After } \\
\text { hemorrhage }\end{array}$ & 14.5 & 31.8 & 15.2 & 4.5 & 41.1 \\
\hline
\end{tabular}

sympathectomized dog at the beginning of the experiment and again at the end of five hours of low blood pressure. The results are given in Table II. After five hours of low blood pressure and diminished blood flow, the normal dog was in shock. The elevated oxygen capacity of the arterial blood indicated the extent of hemoconcentration. In comparison the oxygen capacity of the sympathectomized dog was lower than at the start of the experiment. The venous oxygen content in both dogs was reduced to the same extent, 4.5 volumes per cent, as a result of the diminished blood flow. Acidosis, however, was present in the dog in shock. The arterial carbon dioxide was reduced from 45.2 to 15.1 volumes per cent. In the sympathectomized dog, on the other hand, a comparable degree of acidosis was not present. The carbon dioxide was reduced only from 45.3 to 31.8 per cent.

\section{DISCUSSION}

The importance of an adequate supply of blood to the tissues of the body has been emphasized by many investigators in their studies on the mechanism of shock. Erlanger, Gesell, Gasser and Elliott (11) concluded that the causative factor of shock was " reduced circulation brought about possibly through the action of pain stimuli, and of a certain amount of hemorrhage, on the vasoconstrictor mechanism." Gesell (12), after his studies on the relationship of hemorrhage and "tissue abuse" to the blood flow through the salivary gland stated that the "volume flow of blood appeared to be the more fundamental problem." During the World War, Bayliss (13) wrote: "At the risk of tiresome iteration, I would again emphasize the importance of adequate oxygen supply to the tissues." Johnson and Blalock (14) stressed the importance of a reduction in the output of the heart from a diminished blood volume as the centrally important feature in the development of shock. Since low blood pressure characterizes shock it was natural that attention should have been focused upon this aspect of the problem. Cannon (15) in his monograph on shock stated, "One of the central problems, if not the most important central problem, of shock is that of discovering the reason for the lowered arterial pressure." Porter (16) was the first to call attention to the "critical level" of blood pressure and Cannon (15), in his experiments with cardiac tamponade in cats, found that if the blood pressure were reduced for a period of time below the critical level, $70 \mathrm{~mm}$. $\mathrm{Hg}$, a condition of shock ensued.

Vasoconstriction, since it diminishes the capacity of the vascular bed and thus helps to maintain the blood pressure, has generally been regarded as a beneficial reaction. Through vasoconstriction, however, at the same time that the pressure is maintained in the larger arteries, the "nutrient flow" through the smaller vessels is reduced.

The data in the present experiments indeed show that vasoconstriction initially performs a beneficial function. The normal dogs were able to tolerate a greater loss of blood than were the sympathectomized dogs (Table I). The blood pressure was not reduced to as great an extent even though more blood was lost. The volume flow of blood in the periphery, on the other hand, was reduced to a greater extent. Associated with this reduction in nutrient flow, hemoconcentration took place, and the process of shock was initiated.

From analysis of the relationship of blood pressure to blood flow in the absence of vasomotor impulses (Figure 5), it is clear that the head of pressure was of preeminent importance in regulating the volume flow. Superimposed upon this 
control was that exercised by the vasomotor system (Figure 6). In the normal dog, wide variations in flow were encountered during the period of initial bleeding over the higher ranges of blood pressure. Then, below $70 \mathrm{~mm}$. $\mathrm{Hg}$, the flow was drastically and consistently reduced. We feel it to be of significance that the marked reduction in flow should occur at approximately $70 \mathrm{~mm}$. $\mathrm{Hg}$, the so-called "critical level" (16). At blood pressures below $70 \mathrm{~mm}$. $\mathrm{Hg}$, although the blood flow through the paw of the sympathectomized dog was reduced, the tissues were probably still able to obtain sufficient blood for their needs. Vasoconstriction in the normal dog, at these pressures, still further reduced the blood supply and shock was produced.

Vasoconstriction after hemorrhage serves to protect the vital centers against the harmful effects of a dangerously low blood pressure. The effects of a period of prolonged low pressure on the heart were frequently observed. If blood were too rapidly reinjected after a period of low blood pressure, evidence of acute cardiac failure would supervene. The blood pressure would fall. Recovery could then be effected by withdrawing some of the blood and reinjecting it more slowly. In three of the experiments (Numbers 751, 767, and 2 , Table I), the dogs were killed by too rapid reinjection of blood. Postmortem examination revealed a dilated right heart. The necrosis of the liver cells observed in the sympathectomized dog which was sacrificed (Figure $3, C$ ) may have resulted from the prolonged low blood pressure, but our data are insufficient to warrant drawing conclusions.

The brain is another vital center which is susceptible to injury from low blood pressure. In one of the sympathectomized dogs (385) and in one of the normal dogs which recovered (641), although the blood flow and blood pressure returned to normal after the reinjection of blood, the dogs showed definite signs of cerebral damage, manifested by stupor and extensor rigidity. This observation serves again to stress the useful function of the sympathetic nervous system. By means of vasoconstriction, preferential treatment of blood supply is given to the brain, since the cerebral vessels do not respond as vigorously to vasoconstrictor impulses as do the peripheral vessels (17). The general tissues of the body are deprived of blood in order that the brain may live. After sympathectomy, this preference is lost. All the tissues of the body are accorded the same treatment. If the brain is receiving sufficient blood for its needs, all the tissues of the body are probably adequately supplied. As long as the brain is kept alive in the sympathectomized animal, the tissues will be kept alive also.

Another observation which is in accord with the concept of an inadequate circulation as the fundamental cause of shock is offered by the determinations of the oxygen and carbon dioxide contents of the arterial and venous bloods. In the shocked dog (Table II), there was not only a severe reduction in the oxygen content of the venous blood as a result of the sluggish flow, but the carbon dioxide content was also reduced. This - reduction in the carbon dioxide content, formerly believed to be of significance in the etiology of shock (Acapnea theory of Henderson (18)), is considered at the present time by most investigators to be of importance only in illustrating the acidosis from the accumulation of "fixed acids" which results from an inadequate circulation. In the sympathectomized dog, although the venous oxygen was reduced just as much as in the normal dog in shock, the "acidosis" was not as severe. Although the tissues of the dog which recovered were not receiving as abundant a supply of blood as normally, there was still sufficient oxygen to prevent as great an accumulation of fixed acids as in the dog which died.

The volume flow of blood through the hind paw of the dog is not an exact index of the circulation through other portions of the body. Blalock and Levy (19) have recently presented evidence to show that in shock, the blood flow through the hind quarters of the dog is reduced to a greater extent than that through other regions. In our experiments it has served primarily to illustrate the reduction in circulation brought about by vasoconstriction in comparison to the diminution which resulted from the fall in blood pressure, since the flow through the normal paw was lower than the flow through the sympathectomized paw at comparable low levels of blood pressure. The values obtained for the 
volume flow of blood through the paw in the shocked dogs are in general agreement with previous data obtained on the blood flow through the hand in clinical cases of surgical shock (20). In the present experiments upon normal dogs, when the blood flow was reduced to below 2 cc. per minute, shock was produced. In two normal dogs which recovered, the blood flow was 2.1 and 2.9 cc. per minute. In two of the sympathectomized dogs, however, the blood flow through the paw was reduced to $1.0 \mathrm{cc}$. per minute and yet recovery took place. It seems likely that a minimum blood flow requirement exists, and if the nutritive flow is reduced below this level pathological changes ensue. Our data are insufficient to state precisely at what flow such changes occur.

Recovery took place in two of the normal dogs. In one of these dogs the blood pressure was kept between 50 and $80 \mathrm{~mm}$. $\mathrm{Hg}$ for two hours and in the other for six hours. In both dogs, the flow was rarely reduced below $2 \mathrm{cc}$. per minute. Both dogs showed dilution of the blood. The dogs were calm and phlegmatic, and it was our impression that their lack of fear, in comparison with other normal dogs, prevented them from going into shock, even though the amount of blood lost was approximately the same.

One dog (Figure 4), Number 641, had been about the laboratory for several weeks and was well adjusted to experimental procedures. This dog's blood pressure dropped abruptly to 80 after the first two hemorrhages and yet the blood flow varied between 12 and $19 \mathrm{cc}$. per minute for an hour though the blood pressure ranged from 64 to $82 \mathrm{~mm}$. $\mathrm{Hg}$. In comparison, Dog 25 (Figure 1) was very high strung. After the first two hemorrhages, the blood pressure rapidly built back to $100 \mathrm{~mm}$. $\mathrm{Hg}$ but the blood flow was reduced below 2 cc. per minute. Over the next three hours, although the blood pressure ranged between 76 and $96 \mathrm{~mm}$. $\mathrm{Hg}$ the blood flow stayed below 2 cc. per minute. In the "well adjusted" $\mathrm{dog}$, rapid dilution of the blood took place since the hemoglobin fell from 103 to 75 per cent (16.5 to 11.4 grams per $100 \mathrm{cc}$.) in the course of two hours. In the apprehensive dog, the hemoglobin during a two hour period fell only from 106 to 98 per cent ( 16.6 to 15.3 grams per $100 \mathrm{cc}$.). It is well recognized that fear produces vasoconstriction and a reduction in peripheral blood flow (20).
It is probable that the reduction in blood flow, observed in Dog 25 even before the hemorrhage, was the result of emotional stimulation. After hemorrhage, although the arterial blood pressure was maintained at a higher level as a consequence of the activity of the sympathetic nervous system, the blood flow was so far reduced that it facilitated the process of shock. In Dog 641, the high preliminary level of blood flow before the hemorrhage indicated that the sympathetic nervous system was not being called into activity. Even after hemorrhage, vasoconstriction was minimal. The blood flow continued at a high level, dilution of the blood took place, and the dog recovered.

Similarly, Dog 546 (Table I) recovered although the blood pressure was reduced to 66 for two and one-half hours. At the second experiment on this same dog it was necessary to reduce the blood pressure to an average of 38 for almost four hours before shock was produced. Even so the volume flow of blood through the paw was definitely higher (1.6 cc. per minute) than in the other dogs which went into shock.

In a previous communication, the hypothesis was advanced that the process of shock has its origin in the physiological reactions of the body to traumatic stimuli. By means of activity of the sympathetic nervous system, the body is able to adjust itself to the emergency. If the crisis is too protracted, however, then vasoconstriction, the very mechanism by which the organism strives to survive, brings about its ultimate dissolution. The present experiments on the effects of hemorrhage offer further support to this hypothesis.

\section{SUM MARY}

A condition of shock was produced in normal dogs by means of hemorrhage (Figure 1). This condition was characterized by hemoconcentration, failure to respond to blood transfusion, and characteristic pathological changes in the tissues (Figure 3).

After total sympathectomy, even though the blood pressure was reduced to a lower level, for a longer period of time, shock was not produced (Figure 2). Dilution of the blood took place, there was prompt and beneficial reaction to blood transfusion, and similar pathological changes in the tissues did not occur (Figure 3 ). 
The sympathectomized dogs, however, were unable to tolerate as large hemorrhages as the normal dogs. The blood pressure also fell to a lower level at an earlier period than in the normal dogs (Table I).

The difference in reaction of normal and sympathectomized dogs to hemorrhage was correlated with the peripheral blood flow. In the normal $\mathrm{dog}$, as the blood pressure was reduced by hemorrhage to $70 \mathrm{~mm}$. $\mathrm{Hg}$, the blood flow was reduced below $2 \mathrm{cc}$. per minute (Figure 6). In the sympathectomized dog, at the same level of blood pressure, the blood flow was above 2 cc. per minute (Figure 5).

In two normal dogs which recovered, although the blood pressure was reduced to between 60 and $80 \mathrm{~mm}$. $\mathrm{Hg}$, the blood flow continued above $2 \mathrm{cc}$. It was our impression that the absence of fear in these dogs predisposed them to recovery.

Vasoconstriction in the presence of hemorrhage gives preferential treatment of blood supply to the vital centers, the heart and the brain. In the sympathectomized dog, such preference is lost. All the tissues of the body are accorded the same treatment. As long as the vital centers receive sufficient blood supply, all the tissues of the body probably receive an adequate amount of circulation, and the condition of shock is prevented.

\section{BIBLIOGRAPHY}

1. Editorial, Shock. J. A. M. A., 1933, 100, 46.

2. Moon, V. H., and Kennedy, P. J., Pathology of shock. Arch. Path., 1932, 14, 360.

3. Blalock, A., Shock. Further studies with particular reference to the effects of hemorrhage. Arch. Surg., 1934, 29, 837.

4. Cannon, W. B., The Wisdom of the Body. W. W. Norton and Company, Inc., New York, 1932, p. 51.

5. Schlossberg, T., and Sawyer, M. E. MacKay, Studies of homeostasis in normal, sympathectomized and ergotaminized animals. IV. The effect of hemorrhage. Am. J. Physiol., 1933, 104, 195.

6. Freeman, N. E., Decrease in blood volume after prolonged hyperactivity of the sympathetic nervous system. Am. J. Physiol., 1933, 103, 185.
7. Van Slyke, D. D., and Neill, J. M., The determination of gases in blood and other solutions by vacuum extraction and manometric measurement. I. J. Biol. Chem., 1924, 61, 523.

8. Gregersen, M. I., Personal communication.

9. Freeman, N. E., and Zeller, J. W., The effect of temperature on the volume flow of blood through the sympathectomized paw of the dog with observations on the oxygen content and capacity, carbon dioxide content and $\mathrm{pH}$ of the arterial and venous blood. Am. J. Physiol., 1937, 120, 475.

10. Cannon, B., The effects of progressive sympathectomy on blood pressure. Am. J. Physiol., 1931, 97, 592.

11. Erlanger, J., Gesell, R., Gasser, H. S., and Elliott, B. L., An experimental study of surgical shock. Preliminary report. J. A. M. A., 1917, 69, 2089.

12. Gesell, R., Studies on the submaxillary gland. IV. A comparison of the effects of hemorrhage and of tissue-abuse in relation to secondary shock. Am. J. Physiol., 1918, 47, 468.

13. Bayliss, W. M., Intravenous Injection in Wound Shock. Longmans, Green and Company, London, 1918, p. 69.

14. Johnson, G. S., and Blalock, A., Experimental shock. XII. A study of the effects of hemorrhage, of trauma to muscles, of trauma to the intestines, of burns and of histamine on the cardiac output and on blood pressure of dogs. Arch. Surg., 1931, 23, 855.

15. Cannon, W. B., Traumatic Shock. D. Appleton and Company, New York, 1923, pp. 15 and 63.

16. Porter, W. T., Shock from fat embolism of the vasomotor center. Am. J. Physiol., 1924, 71, 277.

17. Schmidt, C. F., The intrinsic regulation of the circulation in the parietal cortex of the cat. Am. J. Physiol., 1936, 114, 572.

18. Henderson, Y., Acapnia and shock. 1. Carbon-dioxid as a factor in the regulation of the heart-rate. Am. J. Physiol., 1908, 21, 126.

19. Blalock, A., and Levy, S. E., The effect of hemorrhage, intestinal trauma and histamine on the partition of the blood stream. Am. J. Physiol., 1937, 118, 734.

20. Freeman, N. E., Shaw, J. L., and Snyder, J. C., The peripheral blood flow in surgical shock. The reduction in circulation through the hand resulting from pain, fear, cold, and asphyxia with quantitative measurements of the volume flow of blood in clinical cases of surgical shock. J. Clin. Invest., $1936,15,651$. 